\title{
THRESHOLD RANGELAND CONDITION FOR RANGELAND RESTORATION INVESTMENTS AND THE FINANCIAL EQUIVALENT OF LIVEWEIGHT LOSSES DUE TO RANGELAND DEGRADATION
}

\author{
KARA, A. \\ Dicle University Faculty of Agriculture Sur, 21280 Diyarbakır, Turkey \\ (e-mail: abdurrahman.kara@dicle.edu.tr; phone: +90-412-241-1000; fax: +90-412-241-1048) \\ (Received 23 ${ }^{\text {rd }}$ Jan 2019; accepted $6^{\text {th }}$ Mar 2019)
}

\begin{abstract}
In this paper, the relations between live weight (LW) gain of the grazing cows and rangeland condition (RC), LW gain and concentrate supplement and LW gain and genetics of the grazing cows were investigated to quantify LW and body condition score (BCS) losses driven by rangeland degradation to estimate the threshold RC over which rangelands can compensate these losses. This study was conducted in Erzurum Province, Turkey. LW gains were estimated using farmer- animal- and rangeland-related variables during June-August and June-October periods. RC was calculated employing the classical condition assessment method. Ordinary least squares (OLS) were used in data analyses. The results show that a $10 \%$ enhancement or setback in $\mathrm{RC}$ can result in about $10 \mathrm{~kg} \mathrm{LW}$ gain or loss per head. The financial equivalent of these LW gain or losses was 314.6 Turkish lira (TRY) or 59.0 USD (I TRY = 0.1875 USD) per farm, which accounts $15.5 \mathrm{TRY}$ or 2.9 USD per hectare of rangeland. It is concluded that rangeland with an $\mathrm{RC}$ value below 4.3 requires restoration and that cows of higher genetic merit more than crossbred genotypes are not suitable for extensive production in the study area and areas sharing similar agroecological conditions.
\end{abstract}

Keywords: threshold rangeland condition, rangeland restoration investments, grazing cows, live weight gain, body condition score, genetic merit, concentrate supplement, Erzurum, Turkey

\section{Introduction}

As a natural resource, rangeland is the common name for extensive natural landscapes, such as grasslands, shrub lands, woodlands, wetlands and deserts. It is the most common land type that about $50 \%$ of the total land area of the world is covered with rangelands (Holechek et al., 2004). Beside the immeasurable outputs of ecosystem services such as biodiversity, soil fertility, water quality, pollination, they ensure the sustainability of extensive livestock production by providing free of charge forage for the farm animals (Williams et al., 1968; Altın et al., 2005). For that reason, extensively managed livestock production is the most sustainable and common form of agriculture. Although they produce relatively agriculturally low value, rangelands have significant overall, economic and social value due to their geographic magnitude (Schacht and Reece, 2009). For that reason, rangelands with low-input, extensive livestock production have been a way of life and important in sustaining livelihoods for centuries in many areas worldwide (Williams et al., 1968; Gintzburger et al., 2006; Pardini, 2009).

However, heavy grazing is reported to be the most important factor causing the deterioration on rangelands. through replacement of species of higher nutritive value with those of lower nutritive value over time. Especially in public rangelands, continuous heavy grazing, irregular and misuse, accelerated with other type of pressures, such as increasing land demand for industry, urbanization and crop cultivation, results in irreversible changes in botanical composition and undesired 
species become dominant (Gökkuş and Koç, 2001; Holechek et al., 2004; Pardini, 2009). Thus, these valuable ecosystems have been degraded over time and they lost their hay production potential. Because, rangeland degradation means losses of livestock revenues for the national economy, rehabilitation and restoration of the degraded natural rangeland sites is of great importance to increase and maintain productivity.

Rangeland condition is defined as an evaluation of the existing state of health of the vegetation cover in a definite site relative to an expected norm with a given set of prevailing environmental and managerial factors, which measures range deterioration and improvement (Heady, 1975; Koç et al., 2003; Ludwig and Bastin, 2008).

As in intensive livestock production systems, extensive, rangeland dependent dairy cattle production is profitable only with high milk yields and the birth of a calf each year per head of dairy cows, both of which require optimal care and feeding conditions. Dairy cow energy reserves are important indicators of these optimal care and feeding conditions, reflecting the animals' underlying physiological state. Because rangelands have been the main feeding sources especially during the grazing seasons (Kara et al., 2009; Ünal et al., 2010; Sayar et al., 2015), energy reserves of the grazing animals are, of course, closely linked to rangeland condition in extensive production.

One method for determining an animal's energy reserves is the body condition score (BCS). The BCS rates farm animals according to visual and/or tactile appraisals of specific body regions made by trained staff to assess body energy reserves (Aktaş et al., 2011; Berry et al., 2011; Anonymous, 2012). In their review, Bewley and Shulz (2008) concluded that changes in BCS throughout lactation can have an impact on milk yield, herd health, reproductive performance, and animal well-being. Therefore, management of BCS must play a key role in achieving profitable animal production by maximising animal potential.

Modified versions of the BCS have been used in many countries for different kinds of farm animals since it was first developed for sheep by Jefferies (1961). Different countries employ different BCS scoring systems (e.g. 1-4, 1-5, 1-8, 1-9, and 1-10 scales). In all systems, thin animals receive lower scores than fat animals (Bewley and Schulz, 2008).

In addition to BCS, live body weight (LW) is routinely used to estimate the body energy reserves of farm animals. Although changes in LW are influenced by factors other than fat content (e.g. endogenous water and protein content, changing organ weights, gastrointestinal contents, and foetal development) (Schroder and Staufenbiel, 2006), thereby rendering interpretation of LW changes difficult (Morris et al., 2002), it is accepted that LW and LW changes have effects similar to those of BCS (Roche et al., 2007) and that monitoring LW after parturition can be used as a management tool to

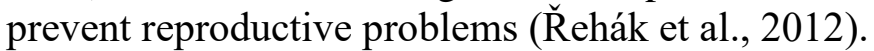

Consequently, the relation between BCS and LW has been the subject of numerous studies. Otto et al. (1991) calculated an $\mathrm{r}^{2}$ of 0.62 for the relation between BCS and LW in US Holstein cows. Enevoldsen and Kristensen (1997) reported correlations between BCS and LW of 0.53, 0.34, and 0.57 for Danish Friesian, Danish Jersey, and crossbred Jersey $\times$ Red Danish cows, respectively. Yildiz et al. (2011) reported a correlation of 0.4 between BCS (1-5 scale) and LW for Brown Swiss $\times$ Simmental crosses. Berry et al. (2011) reported a moderate correlation $(r=0.49)$ between BCS (1-5 scale) and LW for Irish Holstein-Friesian dairy cows in pasture-based dairy cattle production. 
Although LW explains only 25-62\% of the variation in BCS changes, it is still used as an indicator of BCS losses or gains in cows (Anonymous, 2012). In fact, these values underestimate the accuracy of LW as an indicator of BCS since BCS is affected by body shape, and more fat is needed for each additional BCS point on a large-framed than on a small-framed cow, because visual changes in BCS take longer to become apparent (minimum 4 weeks) than do changes in LW (1 or 2 weeks) (Moran, 2005).

Morris et al. (2002) reported that $15-\mathrm{kg}$ and $30-\mathrm{kg} \mathrm{LW}$ increments were necessary to increase BCS by one unit in 1-10 and 1-5 systems, respectively. Berry et al. (2006) reported that, on average, $1 \mathrm{BCS}$ unit equalled $31 \mathrm{~kg}$ in LW. In a later study, Berry et al. (2011) reported a 50-kg LW change per unit change in BCS, varying from 39-66 kg, depending on the parity and stage of the inter-calving interval.

The BCS of farm animals fluctuates throughout the year, and different BCSs have been suggested for certain stages of cow production cycles to maximize economic returns through optimizing milk production while minimizing health and reproductive disorders (DEFRA, 2001). During the parturition and dry-off periods, optimum BCS is expected to be 3 and 4, respectively, and to be between 2 and 3 during peak milk yield (Serin, 2004; DeLaval, 2006; Hulsen, 2007; OMAFRA, 2015). The reason for low BCS during peak milk yield is insufficient daily nutrient intake coupled with higher energy requirements, which lead to a negative net energy balance. To cover the energy gap, the energy reserves of the body are mobilised, which brings about BCS losses after calving. Gallo et al. (1996) pointed out that BCS is lowest in the third and fourth months of lactation in low- and high-yielding animals, respectively, and it is compensated for only in the middle of or at the end of lactation, although replacement of decreased body fat reserves starts in the seventh and twelfth weeks after calving.

With one third of total rangeland asset, Eastern Anatolia ranks first among the geographical regions of Turkey. Not only is arable land limited due to varied topography but also crop pattern because of short vegetation period and low mean temperature. Consequently, rangeland dependent extensive animal production has been an important component for livelihoods of the rural people from past to present. In this region and especially in the study area, calving occurs in February and March, and rangeland grazing starts by early May (Kara et al., 2009). The beginning of the grazing season coincides with the $60^{\text {th }}-90^{\text {th }}$ day of lactation, when BCS is lowest. In the study area, cow BCS is likely <2.5, and even drops as low as 2.1 (Aktaş et al., 2011).

Given that the only nutrient source for grazing cows is rangeland herbage (except in the early and late grazing season; Kara et al., 2009), high-quality rangeland is necessary to compensate for BCS and LW losses and achieve profitable production in extensive farming. However, the decades-long use of rangeland above its carrying capacity has resulted in deteriorating rangeland quality and losses in herbage production potentials. Therefore, rehabilitation of degraded rangeland can lead to LW and BCS gains, ultimately leading to an increase in beef and milk production for the local farmers whose livelihoods depend on animal production.

Although an increasing awareness has been developed on the importance of rangelands worldwide and the governments allocate considerable funds to restore degraded rangelands it is necessary to keep the rangelands on the top of the list in the agenda in facilitating sustainable fund allocation to rangeland restoration investments providing cause-effect results with some concrete data. This article covers an on-farm research study of 11 carefully selected villages and their rangelands in a socioeconomic environment. By connecting rangeland and grazing animal attributes in extensive dairy 
cattle production at farm level, I aimed to quantify LW and BCS losses driven by rangeland degradation to estimate the threshold $\mathrm{RC}$ over which rangelands can compensate BCS and LW losses, and under which restoration is required.

I also aimed to grasp attention of the policy makers to the importance of rangeland restoration efforts and discuss the importance of sustainable rangeland use from a different view point by revealing the effect of rangeland degradation on LW and BCS losses and calculating the cost equivalent of the feeds required to compensate for the LW or BCS losses. Study results may also be important for researchers and the others having an interest on rangeland-animal relationships prevailing under on-farm conditions. Although the study presents results and arguments from Erzurum Province, Turkey, the findings are expected to be relevant to countries sharing similar agroecological conditions, production patterns, and cultural and historical backgrounds.

\section{Materials and methods}

\section{Materials}

The primary study materials were vegetation study results and LW records of lactating cows in farms selected from the study villages. Secondary materials included official records of the Eastern Anatolia Agricultural Research Institute and other relevant official institutions.

\section{Methods}

\section{Study area}

The study area covers Erzurum Province, which is representative of the entire region in terms of topography, altitude, climate, and production pattern (Fig. 1). It has $12 \%$ and $10 \%$ of the total meadow and rangeland pastures in Turkey, respectively (TURKSTAT, 2013). A continental climate prevails, with long harsh winters and short hot summers. The lowest and highest recorded temperatures between 1975 and 2006 were $-37.2^{\circ} \mathrm{C}$ and $36.5^{\circ} \mathrm{C}$, respectively, while average annual temperature and rainfall were $5.5^{\circ} \mathrm{C}$ and $453 \mathrm{~mm}$, respectively. The number of frosty days was 154, and the number of days with snow cover was 113 (TÜMAS, 2013). The average annual rainfalls in 2006 and 2007 were $357.4 \mathrm{~mm}$ and $436.6 \mathrm{~mm}$, respectively, of which 43.4 and $134.1 \mathrm{~mm}$ were recorded from June-August in the first and second grazing seasons, respectively, a difference of $90.7 \mathrm{~mm}$. Despite the positive difference in annual precipitation between the first and second study years, there was considerably more rain in SeptemberOctober in 2006 than in 2007 (Table 1).

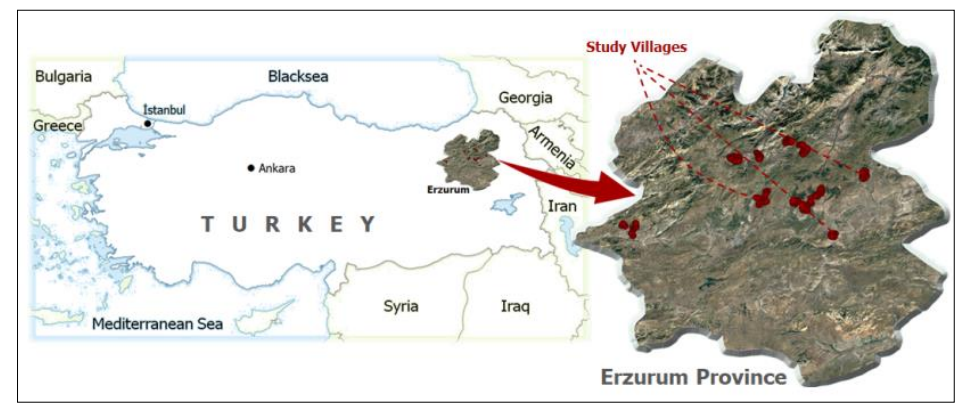

Figure 1. The study area 
Table 1. Precipitation in June-August and June-October periods of the grazing seasons (mm)

\begin{tabular}{c|c|c|c|c}
\hline Grazing Season & June-August & June-October & September-October & Annual Total \\
\hline 2006 & 43.4 & 162.7 & 119.3 & 357.4 \\
2007 & 134.1 & 167.9 & 33.8 & 436.6 \\
Difference & 90.7 & 5.2 & -85.5 & 79.2 \\
\hline
\end{tabular}

Source: TÜMAS (2013)

Indigenous cattle breeds and their various crosses constitute the largest ruminant population, whereas Red Karaman sheep and Anatolian Black goats make up the smallruminant assets in the region (Kara and Kizıloğlu, 2012). They are hardy and well adapted to natural rangeland. In Figure 2 are presented some photos to illustrate the study area rangelands.
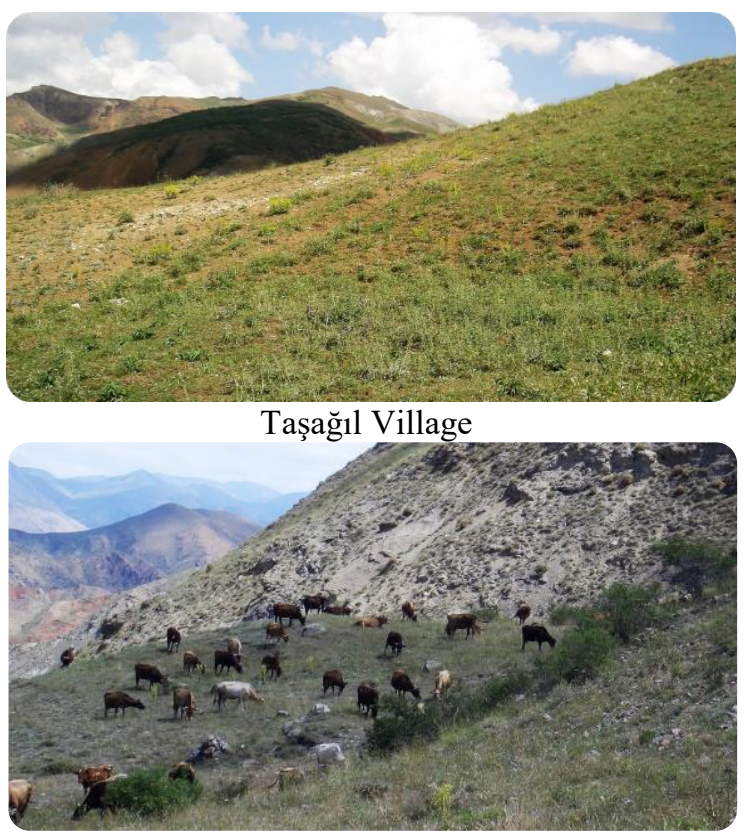

Esendurak Village

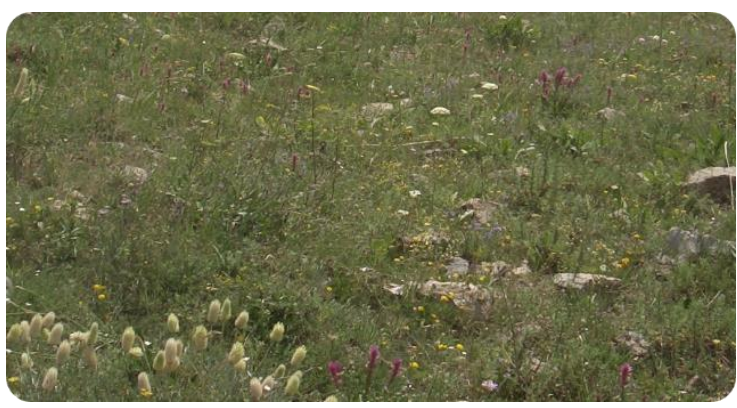

Tipili Village

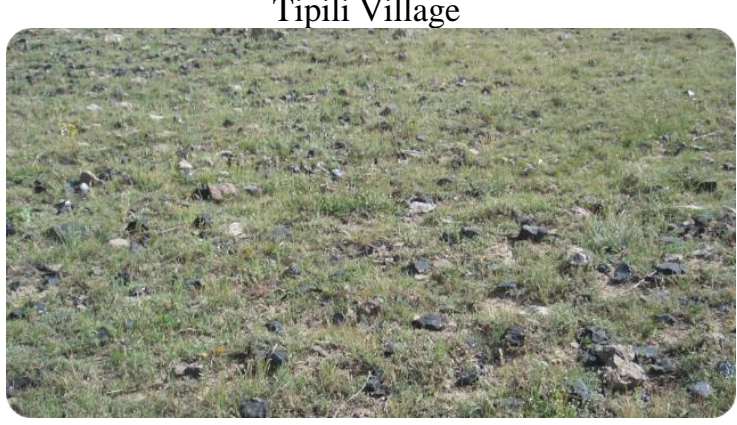

Yayladağ Village

Figure 2. The study area rangelands

\section{Selection of villages}

Based on how well they represented the surrounding area and province as a whole, villages were selected from different districts, both east-west and north-south, that were free of nomadic movements and boundary problems and for which rangeland demarcation and allocation studies were completed. In total, 11 villages were selected from Aşkale, Yakutiye, Tortum, Narman, Pasinler, Köprüköy, and Horasan districts. Although the selected villages dispersed in different districts of Erzurum province, there was no significant differences among them regarding climatic conditions, production techniques, customs and the habits. At least, it was assumed that the only factors differentiate the villages from each other were the condition of their rangelands, the altitude and the stocking rate. 


\section{Vegetation studies and calculation of the rangeland condition}

Vegetation studies were carried out in 2006 to determine the botanical composition and conditions of the village rangeland. They were conducted in 12 representative sites in rangelands of each village with four replications along 100-m transects in easterly, westerly, southerly, and northerly directions, following Koç and Çakal (2004). The condition of the rangeland was determined following the methods of De Vries et al. (1951), cited in Koç et al. (2003), using the vegetation study data for each site in every village.

Rangeland condition was calculated according to the Rangeland Quality Degrees method (De Vries et al., 1951, cited in Koç et al., 2003), using the equation given below.

$$
R_{\text {Condition }}=\sum P_{i} \times Q S_{i}
$$

In Equation 1, $\mathrm{P}_{\mathrm{i}}$ shows the relative abundance of each species, calculated as the proportion of individuals of $i^{\text {th }}$ species to the total number of individuals encountered in the studied site, as $Q S_{i}$ represents the quality score of the $\mathrm{i}^{\text {th }}$ species. Quality score reflects the values given to each species according to the grazing and productivity traits of the encountered species such as productivity, post-grazing regeneration ability and palatability, varying between -1 to 10 . Poisonous plants take -1 point as the scores 1 to 10 indicate the degree of other desirable traits (Koç and Gökkuş, 1996; Altın, 2001; Koç et al., 2003). In this method, vegetation cover is accepted as the product of climate and soil, as such that information on climax vegetation is not needed.

The arithmetic means of 12 sites in each village were used as a measure of the village's overall degree of rangeland quality. Rangeland condition was given a value between 0 and 10 (0-2.0: very poor, 2.1-4.0: poor, 4.1-6.0: moderate, 6.1-8.0: good, and 8.1-10.0: very good).

\section{LW measures}

The LWs of grazing lactating cows from the selected farms were measured and recorded by the study staff using digital scales three times per year during the study: at the beginning (early June), in the middle (late August), and at the end of the grazing season (late October). The scales were calibrated at the time of each weighing in every study village.

To reveal the effect of concentrated supplements on LW gain, each lactating grazing cow was regularly supplied with supplements on a daily basis (1 $\mathrm{kg}$ manufactured milking concentrate) during the grazing season. About half the study farms were provided with milking concentrate $\left(16 \%\right.$ crude protein and $2,400 \mathrm{Kcal} \mathrm{kg} \mathrm{kg}^{-1}$ metabolic energy) in the first year, and the rest were provided with it in the following year. The amount of concentrate was standardised using a 1-kg capacity pan.

\section{Data analysis}

Forage allowance is high in June to August and thereafter continuously declines until the end of the season due to grazing and the maturation of the vegetation respectively. For that reason, the LW gain of the grazing cows in randomly selected farms in 11 studied villages was calculated for two periods (June-August and June-October) for each lactating cow by subtracting the initial LW from that measured in the middle and 
at the end of the grazing season. In the socioeconomic environment of extensive production systems, many factors interact and affect the LW gain of grazing animals. Some of these factors relate to farmers (age, education) and some relate to the attributes of the grazing animals (e.g., lactation order and LW at the beginning of the grazing period), whereas other factors are related to the rangeland itself (e.g., rangeland condition, bare ground, altitude, and stocking rate), which determine herbage production and quality.

Considering the fact that most of the variables under consideration are affected by more than one cause in the real world, it is important to isolate multiple independent variables affecting the dependent variable in the model of interest. This feature can be achieved at ceteris paribus, which means "holding other things constant". The assumption of ceteris paribus is important to determine causation, especially in economics. Linear regression, on the other hand, is the workhorse of the econometrics and ordinary least squares (OLS) method is the most popularly used method to estimate the regression coefficients and describes well the relationship between dependent and independent variables in the presence of ceteris paribus assumption (Gujarati, 2012).

Moreover, the linear estimators, i.e., the regression coefficients, are easy to understand and simple to deal with. It is easier to explain the effect of independent variables on a dependent variable (Gujarati, 1995). However, Baltagi (2005) warns that individuals, firms, states, countries, etc., are heterogenous units and if not controlled this heterogeneity, the studies considering other than the panel data will have the risk of obtaining biased results. The most prominent techniques used to analyze panel data are fixed effect and random effect models. If a specific set of $\mathrm{N}$ entities (e.g., firms, countries, cities or the villages as in the present study) is focused on and the inferences have to be restricted to the behavior of these entities or whenever the aim is to analyze the impact of variables that vary over time, the fixed effects model is appropriate and therefore should be used (Baltagi, 2005; Torres-Reyna, 2007).

In the present study, however, as stated earlier, the study villages share the same agro-ecological conditions and production pattern, habits and customs inherited from the past. I assumed that heterogeneity among the villages was solely due to rangeland condition, altitude, and stocking rate. Further, I also assumed that heterogeneity among the farmers was due to their age and education level. As observation units, the cows were differentiated in terms of their lactation orders, initial LWs and breeds, all of which were controlled with relevant variables in the models.

In this study, I would like to reveal the effect of rangeland condition on LW gain in a two-year study and rangeland condition is a long-time concept (Heady, 1975), i.e., it is time invariant and does not change for several years. For that reason, it had a fixed value for each village during the study years. Only the average rangeland condition and average altitude value were calculated and assigned to each selected village, which is a significant limitation and makes it impossible to run fixed effect panel data models for the study data. In case of setting or treating the village variable as a panel variable, the rangeland condition, stocking rate, and altitude variables are dropped out. Whereas the rangeland condition is the backbone of the research and dropping it out would render the whole study inconclusive.

On the other hand, unlike the fixed effects model, the variation across entities is assumed to be random and uncorrelated with the predictor or independent variables included in the model (Torres-Reyna, 2007). The random effects model is appropriate if a set of $\mathrm{N}$ entities are randomly selected from a large population. If there is a reason to 
believe that the differences across entities (the villages here) have some influence on the dependent variable (e.g., rangeland condition in the present study), then RE seems to be the most appropriate and so should be used (Baltagi, 2005; Torres-Reyna, 2007). Nevertheless, following the Breusch-Pagan Lagrange Multiplier test with a null hypothesis suggesting the use of simple OLS regression, we found it to be more appropriate ( $p>0.05$ ) for the present study (Torres-Reyna, 2007; Gujarati, 2012).

OLS linear regression model can be written as in Equation 2 given below (Gujarati, 1995);

$$
Y_{i}=\beta_{1}+\beta_{2} X_{2 i}+\beta_{3} X_{3 i}+\cdots+\beta_{k} X_{k i}+u_{i}
$$

where;

- $Y$ represents dependent variable.

- $X$ represents explanatory (independent variables).

- $\beta_{1}$ represents intercept.

- $\beta_{2}$ to $\beta_{k}$ represent slope coefficients.

- $k$ represents $\mathrm{k}^{\text {th }}$ coefficient.

- $i$ represents $\mathrm{i}^{\text {th }}$ observation.

- $u$ represents random or stochastic error term.

In a linear regression analysis following assumptions should be met (Gujarati, 1995);

- There is no multicollinearity (exact linear relationship) among the independent variables.

- Error term has a homoscedastic (constant) variance.

- Error terms are not correlated with each other, that is, there is no autocorrelation among error terms.

- Error terms are normally distributed.

In the regression models, categorical variables were represented by dummy variables whose number was less by one than that of the classification of the qualitative variables (Gujarati, 2012). In our study, the variable of the cow breed had three categories including local cattle breed. Thus, it was represented by two dummies of crossbred and purebred. Since the dummy variable for local breed was not included in the regression models, coefficients of other dummy variables should be interpreted in relation to reference category (local breed) as coefficients of other continuous independent variables represent the marginal change in dependent variable as a result of one-unit change in the continuous dependent variable of interest at ceteris paribus.

LW gain of the grazing cows was considered to be a function of the continuous and discrete variables given in Table 2.

The F-test and Ramsey RESET test were used to determine the significance and the omitted variables of the model, respectively. Multicollinearity was controlled with the variance inflation factor. Heteroskedasticity was tested with the Breusch-Pagan test, and the normality assumption was controlled with skewness and kurtosis tests, along with the Graph Method (Neter et al., 1989; Gujarati, 1995; Callaghan and Chen, 2008; Park, 2008; Cameron and Trivedi, 2010). Autocorrelation was not tested due to the fact that it is the problem of time series data and the data used in the present study is crosssectional (Gujarati, 1995).

The skewness and kurtosis tests appeared to suggest that the assumption of the normality of the residual was violated. However, despite some small deviations that 
could be omitted, the normal probability and quantile-quantile plot distributions of the residuals indicated this was not the case (Park, 2008; Anonymous, 2013).

As the variable 'altitude' caused serious multicollinearity problem and inconsistent estimators for the models, it was omitted. Similarly, 'concentrate supplement $\times$ season' and 'concentrate supplement $\times$ animal breed' interactions were not included into the model because they also caused serious multicollinearity problems. According to the variance inflation factor values (range: 1.02-2.38, mean: 1.48), the regression models without altitude variable and above-mentioned interaction terms did not have a serious multicollinearity problem (Gujarati, 1995; Callaghan and Chen, 2008; Park, 2009). However, the Breusch-Pagan test revealed that the model had heteroskedasticity problem $(\mathrm{p}<0.01)$ and to correct this problem Robust Standard Errors procedure was applied (Gujarati, 2012). Moreover, the Ramsey RESET test proved that the model had no omitted variable bias $(\mathrm{p}=0.32)$. Stata $\mathrm{SE} 14$ software package was used for all analyses.

Table 2. Explanations of the study variables

\begin{tabular}{|c|c|}
\hline Variables & Explanations \\
\hline LW Gain-1 & LW gain of grazing dairy cows during June-August period $\left(\mathrm{kg}^{2}\right.$ head $\left.^{-1}\right)$ \\
\hline LW Gain-2 & LW gain of grazing dairy cows during June-October period $\left(\mathrm{kg} \cdot\right.$ head $\left.^{-1}\right)$ \\
\hline Distance & Approximate distance between village and rangeland site $(\mathrm{m})$ \\
\hline Farmer Age & Age of the farmer (year) \\
\hline Schooling & Education level of the farmer (in schooling years) \\
\hline Rangeland Condition & Rangeland condition (rangeland quality) \\
\hline Altitude & Average altitude of the village rangelands (m) \\
\hline Lactation Order & Lactation order (number of giving birth) of the cows \\
\hline Initial LW & Live weights of the cows at the beginning of the grazing period $(\mathrm{kg})$ \\
\hline Stocking Rate & Rangeland stocking rate (animal unit (AU) per hectare) \\
\hline Bare Ground & Bare ground percentage of the village rangeland $(\%)$ \\
\hline Season & Grazing season $(1=$ Second year; $0=$ First year $)$ \\
\hline Crossbred & Crossbred cows (If crossbred 1 , otherwise 0 ) \\
\hline Purebred & Purebred cows (If purebred 1, otherwise 0 ) \\
\hline Concentrate Supplement & Supplement feed during grazing season $(1=$ Yes, $0=$ No $)$ \\
\hline Season $\times$ Supplement & Season $($ Year $) \times$ Supplement feed interaction \\
\hline Crossbred $\times$ Supplement & Crossbred $\times$ Supplement feed interaction \\
\hline Purebred $\times$ Supplement & Purebred $\times$ Supplement feed interaction \\
\hline$U$ & The error term \\
\hline
\end{tabular}

The data for the variables of rangeland condition, altitude, distance, and bare ground were obtained from the vegetation studies and the live weight data were obtained from the live weight measures of the farm animals as stated earlier. The data used for stocking rate calculations were from the official records of the provincial and district directorates of agriculture.

\section{Results}

\section{Vegetation survey results}

The rangeland attributes of the study villages are presented in Table 3. As mentioned by Kara et al. (2015), 140 different species were found in the studied rangeland, of which 26, 24, and 90 were species of legumes, grasses, and other families respectively.

Medicago varia (5.0\%), Astragalus lineatus (3.3\%), Astragalus microcephalus (1.9\%), Trifolium hybridum (1.7\%), Coronilla varia (1.4\%), and Astragalus lagurus 
(1.3\%) were the most common legumes, whereas Festuca ovina (13.3\%), Stipa lagascae (3.3\%), Agropyron intermedium (3.1\%), Dactylis glomerata (1.5\%), Bromus tectorum (1.3\%), and Phleum montanum (1.3\%) were the most common grasses. The most widespread species of other families were Thymus pubescens (6.7\%), Artemisia spicigera (3.4\%), Salvia candidissima (3.0\%), Eryngium campestre (2.8\%), Galium verum (2.6\%), Achillea millefolium (2.4\%), Verbascum cheiranthifolium (2.1\%), Plantago atrata (2.1\%), Helichrysum plicatum (2.0\%), Tanacetum balsamita (1.7\%), Alyssum pateri (1.5\%), Acantholimon caryophyllaceus (1.4\%), Artemisia austriaca (1.4\%), and Euphorbia virgata (1.3\%).

Table 3. Rangeland attributes of study villages

\begin{tabular}{c|c|ccc|c|c|c}
\hline Villages & $\begin{array}{c}\text { Species } \\
\text { Richness }\end{array}$ & $\begin{array}{c}\text { Of Species Found in Rangeland } \\
\text { Vegetation }(\%)\end{array}$ & $\begin{array}{c}\text { Rangeland Condition } \\
\text { (in fragments of 10) }\end{array}$ & $\begin{array}{c}\text { Bare Ground } \\
(\%)\end{array}$ & $\begin{array}{c}\text { Altitude } \\
(\mathbf{m})\end{array}$ \\
\hline 1 & 64 & 17.9 & 30.4 & 51.7 & 3.70 & 29.3 & 2202.3 \\
2 & 66 & 16.4 & 34.0 & 49.6 & 3.26 & 29.7 & 1921.4 \\
3 & 56 & 22.4 & 28.7 & 48.9 & 3.46 & 21.4 & 2269.4 \\
4 & 36 & 6.2 & 25.3 & 68.5 & 2.53 & 27.5 & 2192.8 \\
5 & 58 & 17.5 & 29.7 & 52.8 & 3.19 & 28.7 & 1862.1 \\
6 & 54 & 17.2 & 22.3 & 60.5 & 2.95 & 28.3 & 1723.9 \\
7 & 62 & 15.3 & 23.4 & 61.3 & 2.79 & 15.9 & 2010.2 \\
8 & 58 & 25.6 & 24.6 & 49.8 & 3.73 & 17.9 & 2221.2 \\
9 & 57 & 12.0 & 35.0 & 53.0 & 2.77 & 30.3 & 1775.1 \\
10 & 51 & 29.4 & 36.2 & 34.4 & 4.18 & 27.7 & 2515.2 \\
11 & 62 & 29.2 & 21.8 & 49.0 & 3.60 & 25.0 & 2298.7 \\
\hline Average & 56 & 20.0 & 27.6 & 52.4 & 3.28 & 24.1 & 2135.8 \\
\hline
\end{tabular}

\section{Descriptive statistics}

Average number of lactating cows per farm was 8.5 head. They had an average LW of $287.1 \pm 1.8 \mathrm{~kg}$ at the beginning of the grazing season and gained $16.1 \pm 0.9 \mathrm{~kg}$ and $14.9 \pm 1.0 \mathrm{~kg}$ per head in June-August and June-October, respectively. The lactation orders of the cows were between 1 and 13 . The rangeland condition of the study village rangeland varied from 2.53 to 4.18 , indicating poor to moderate condition. About $24 \%$ of the rangeland area was bare, without any plant covers. The average stocking rate in the studied villages' rangeland was $0.68 \mathrm{AU}$ ( $1 \mathrm{AU}$ equals to $500 \mathrm{~kg} \mathrm{LW}$ ) per hectare varying between 0.1 and 3.0.

\section{Multiple regression analysis}

The factors affecting LW gain per head of dairy cows in June-August and June-October periods in two grazing seasons were examined using OLS regression (Tables 4 and 5).

Season, farmer age, rangeland condition and breed of the cows had all positive and very significant effects $(\mathrm{p}<0.01)$ as concentrate supplements had also significant impact ( $\mathrm{p}<0.05$ ) on LW gain of the grazing cows (Table 4). Additionally, the effects of initial LW of the cows, stocking rate, and bare ground of the rangelands on LW gain were all negative and very significant $(\mathrm{p}<0.01)$. Distance from the village to rangeland, schooling years of the farmers and lactation order of the grazing cows had not significant effect on LW gain $(p>0.05)$. 
Table 4. Multiple regression analysis results with robust standard errors procedure for June-August period

\begin{tabular}{c|c|c|c|c}
\hline LW Gain-1 & Coefficient & Robust Std. Err. & $\mathbf{t}$ & $\mathbf{P}>\mathbf{| t |}$ \\
\hline Season & 18.7042 & 1.6560 & 11.30 & 0.000 \\
Farmer Age & 0.3323 & 0.0702 & 4.73 & 0.000 \\
Schooling & 0.4733 & 0.3386 & 1.40 & 0.162 \\
Distance & -0.0025 & 0.0016 & -1.53 & 0.127 \\
Rangeland Condition & 12.2968 & 1.6597 & 7.41 & 0.000 \\
Crossbred & 9.0896 & 1.9258 & 4.72 & 0.000 \\
Purebred & 23.5637 & 4.3770 & 5.38 & 0.000 \\
Concentrate Supplement & 3.4844 & 1.4592 & 2.39 & 0.017 \\
Lactation Order & -0.0598 & 0.3581 & -0.17 & 0.867 \\
Initial LW & -0.1481 & 0.0214 & -6.93 & 0.000 \\
Stocking Rate & -5.4770 & 1.2610 & -4.34 & 0.000 \\
Bare Ground & -0.4797 & 0.1484 & -3.23 & 0.001 \\
Constant & 4.1739 & 8.9289 & 0.47 & 0.640 \\
\hline
\end{tabular}

Number of observations $=1019 ; \mathrm{F}=45.39 ; \mathrm{p}=0.000 ; \mathrm{R}$-squared $=0.3182$

Similar results can be seen in Table 5, with the exceptions that contribution of age and schooling years of farmers were negative and insignificant, as effect of bare ground was positive but not meaningful. Again, the effect of concentrate supplement shifted from significant to very significant as the effect of distance was altered to marginally significant.

Table 5. Multiple regression analysis results with robust standard errors procedure for June-October period

\begin{tabular}{c|c|c|c|c}
\hline LW Gain-2 & Coefficient & Robust Std. Err. & $\mathbf{t}$ & $\mathbf{P}>|\mathbf{t}|$ \\
\hline Season & 21.1888 & 1.8120 & 11.69 & 0.000 \\
Farmer Age & -0.0091 & 0.0765 & -0.12 & 0.905 \\
Schooling & -0.3132 & 0.3937 & -0.80 & 0.426 \\
Distance & -0.0031 & 0.0017 & -1.86 & 0.063 \\
Range Condition & 13.4401 & 1.9577 & 6.87 & 0.000 \\
Crossbred & 10.5889 & 2.2512 & 4.70 & 0.000 \\
Purebred & 25.9715 & 4.3310 & 6.00 & 0.000 \\
Concentrate Supplement & 4.7480 & 1.6464 & 2.88 & 0.004 \\
Lactation Order & -0.4559 & 0.4236 & -1.08 & 0.282 \\
Initial LW & -0.1756 & 0.0250 & -7.03 & 0.000 \\
Stocking Rate & -4.6123 & 1.4598 & -3.16 & 0.002 \\
Bare Ground & 0.2049 & 0.1747 & 1.17 & 0.241 \\
Constant & 10.7721 & 10.3155 & 1.04 & 0.297 \\
\hline
\end{tabular}

Number of observations $=1019 ; \mathrm{F}=35.73 ; \mathrm{p}=0.000 ; \mathrm{R}$-squared $=0.2997$

The OLS regression results revealed that season had a strongly significant effect on LW gain in both models. There was a positive LW gain difference between the first and second grazing seasons; specifically, there was a difference of about 16.1 and $14.9 \mathrm{~kg}$ per head in June-August and June-October, respectively (Table 6).

Table 6. LW gain of cows by grazing season

\begin{tabular}{c|c|c|c|c|c|c}
\hline \multirow{2}{*}{ Grazing Season } & \multicolumn{3}{|c|}{ June-August Period } & \multicolumn{3}{c}{ June-October Period } \\
\cline { 2 - 7 } & $\mathbf{N}$ & Mean & Se & N & Mean & Se \\
\hline 2006 & 492 & 4.71 & 1.199 & 492 & 2.16 & 1.224 \\
2007 & 527 & 26.79 & 1.063 & 527 & 26.83 & 1.290 \\
\hline Total & 1019 & 16.13 & 0.870 & 1019 & 14.92 & 0.971 \\
\hline
\end{tabular}


The effect of cow breeds or genetic on LW gain was also very significant ( $\mathrm{p}<0.001)$. According to Table 4 and Table 5 crossbred and purebred cows gained 9.1 and $23.6 \mathrm{~kg}$ per head more LW than local cows during June-August and 10.6 and $26.0 \mathrm{~kg}$ per head during June-October periods respectively at ceteris paribus.

However, when I consider the non-supplemented groups in both grazing seasons, it is obvious that performances of the different breeds or genotypes differed in June-August and June-October periods of the grazing seasons. Indigenous or local cows seemed to be hardier and more insensitive for environmental conditions whereas high genetic merit cows, crossbred and especially purebred cows, are more sensitive. For example, considering the June-August period high genetic cows acted in opposite directions. They lost much weight in draught season as gained much in humid season (Fig. 3).
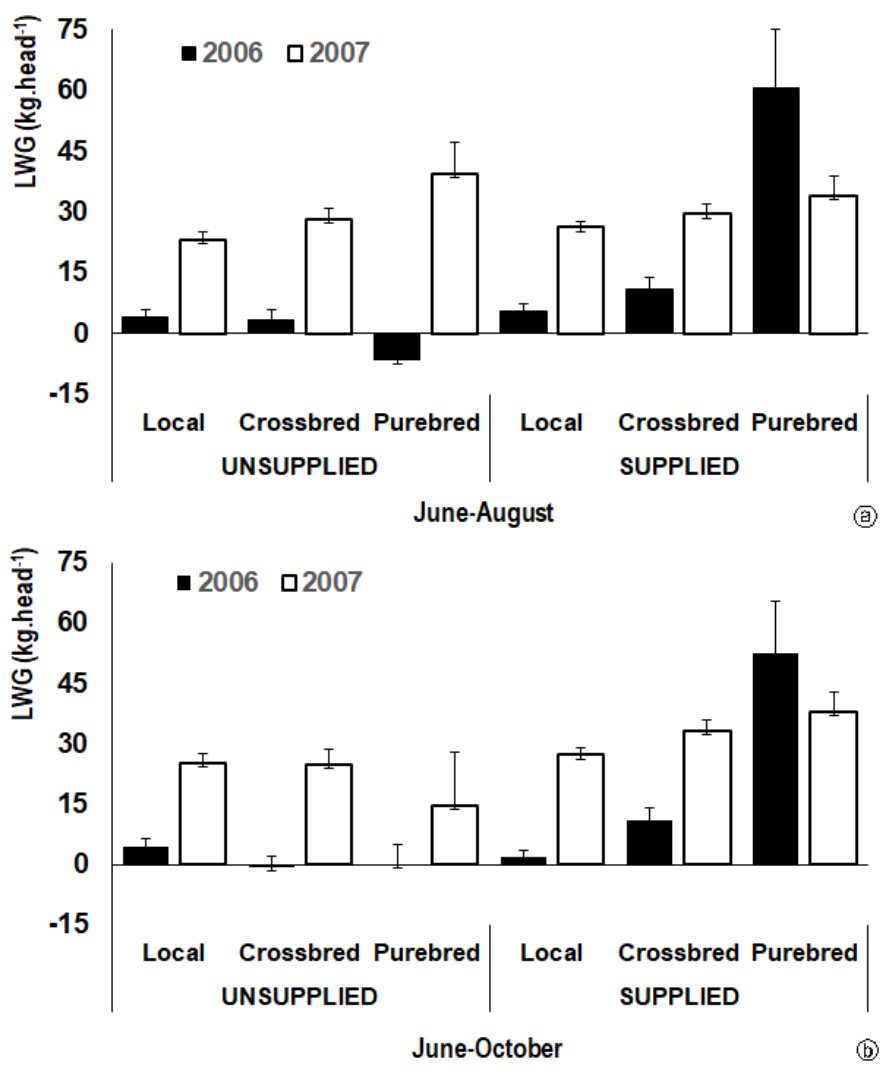

Figure 3. Effect of concentrate supplement on $L W$ gain by grazing seasons and cow breeds a) June-August period, b) June-October period

Yet, as the season advanced, purebred cows did not maintain LW gain and lost much of what they gained during June-August period in humid season. It is also obvious that purebred cows lost LW during June-August period as local and crossbred cows gained some LW in draught season (2006). Again, another remarkable finding is that purebred cows balanced the LW losses at the end of June-October period through the late rainfalls in the draught season (Fig. 3 and Table 1).

The use of concentrate supplement during the grazing season improves LW gain because it enhances animal performance, thereby increasing LW. For that reason, the effect of concentrate supplement on LW gain was also significant $(\mathrm{p}<0.05)$ and very significant $(\mathrm{p}<0.01)$ in June-August and June-October periods, respectively. 
Concentrate supplementation increased LW $3.1 \mathrm{~kg}$ per head and $4.4 \mathrm{~kg}$ per head in these periods respectively (Tables 4 and 5).

More importantly, however, the LW gain due to supplement feed was well below that due to rangeland condition. Tables 4 and 5 show that a $10 \%$ increase in rangeland condition was associated with $12.3 \pm 1.6$ and $13.4 \pm 2.0 \mathrm{~kg}$ LW gains per head of cow in June-August and June-October, respectively. This is 3.5 and 2.8 times the LW gain $(3.5 \pm 1.5 \mathrm{~kg}$ and $4.8 \pm 1.6 \mathrm{~kg}$, respectively) provided by a daily supplement of $1 \mathrm{~kg}$ of concentrate in June-August and June-October, respectively.

\section{LW losses as proxies for BCS losses due to rangeland degradation}

$\mathrm{RC}$ was found to be one of the most important factors affecting LW gains in extensive dairy farming (Tables 4 and 5). LW gain as a result of the impact of RC can be converted to BCS following Berry et al. (2011).

Berry et al. (2011) quantified $39 \mathrm{~kg} \mathrm{LW}$ per 1-unit BCS (1-5 scale) for Holstein-Friesian cows with a LW of $564 \mathrm{~kg}$; this would be $6.9 \%$ of the total LW of the cow. The average amount of weight gain/loss for every unit of BCS change was found to be equivalent to $6.58 \%$ of a cow's total LW on the 1-10 scaling BCS system used in New Zealand (Anonymous, 2012). These two conversions of LW gain or loss for every unit of BCS are roughly the same despite the different scaling systems. However, this can be explained by the fact that the 10-point scale is essentially a 5-point scale, as, in practice, only 3-7 is generally used in New Zealand (Morris et al., 2002).

This study related BCS to changes in LW due to the impact of RC throughout the June-August grazing period. To this end, the findings reported by Berry et al. (2011) regarding the relation between the $\mathrm{BCS}$ and $\mathrm{LW}$ for the post-calving stage $\left(101^{\text {st }}\right.$ to $200^{\text {th }}$ day) were adapted for the present study.

As previously stated, in north-eastern Anatolia, calving occurs in February and March, and rangeland grazing starts by early May (Kara et al., 2009). Therefore, the beginning of the grazing season occurs between the $60^{\text {th }}$ and $90^{\text {th }}$ day of lactation, coinciding with the time of the lowest BCS (Fig. 4).

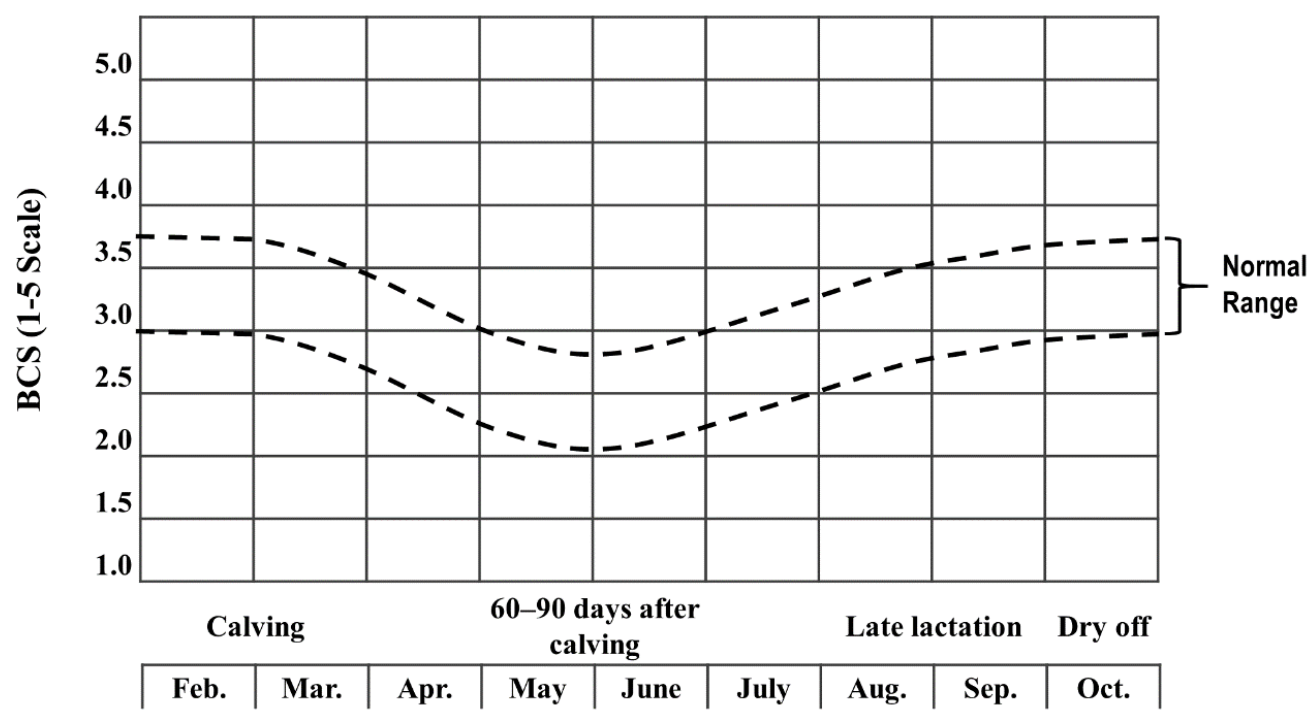

Figure 4. Approximation of BCS changes in dairy cows after calving in the extensive dairy farming system in Erzurum province, Turkey, Source: Adapted from Hulsen (2007) 
The grazing period considered in the present study roughly overlapped with the postcalving stage reported by Berry et al. (2011). The relation between BCS and LW for post-calving reported by Berry et al. (2011) was adapted for this study, although the breed and parity of the grazing cows in the study area were mixed. However, Nielsen et al. (2003) documented no significant effect of breed or parity on the relation between LW and BCS.

The average LW of the cows at the beginning of the grazing period was 287.1 $\pm 1.8 \mathrm{~kg}$ per head of cow. Using the rate of $6.9 \% \mathrm{LW}$ gain per BCS point from Berry et al. (2011), I calculated $19.8 \mathrm{~kg} \mathrm{LW}(287.1 \mathrm{~kg} \times 6.9 \%)$ per BCS point at this stage. Because a $10 \%$ increase or decrease in RC would cause a $12.3 \pm 1.7 \mathrm{~kg} \mathrm{LW}$ gain or loss (Table 4), it can be inferred that a $10 \%$ (one unit) degradation in RC will cause more or less a 0.5 point of BCS loss in the study area and in areas with similar conditions.

The average LW gain at the end of the June-October period was about $15 \mathrm{~kg}$ $(302.0 \mathrm{~kg}-287.1 \mathrm{~kg})$. That is, the BCS of grazing cows increased by only 0.75 points, not fully compensating for a 1-point BCS loss.

This study also revealed that, after August, grazing cows started to lose LW (Table 6), although expected to compensate fully for BCS losses before dry off. As calculated above about $20 \mathrm{~kg}$ of LW gain were required to increase BCS by one point.

\section{Financial equivalent of $L W$ and BCS losses due to rangeland degradation}

The financial equivalent of LW and/or BCS losses due to the degradation of rangeland used by grazing dairy cows can be quantified by calculating the cost of feed required to compensate for $\mathrm{BCS}$ or LW losses. In calculation, barley, the most frequently and easily accessible feed on the farms, was considered. In general, one $\mathrm{kg}$ of barley contains $90 \%$ dry matter and has a metabolic energy value of about 13 mega joules per $\mathrm{kg}$ dry matter (Anonymous, 2015). Following this, financial equivalent of LW losses per farm due to 10 percent rangeland degradation (the energy cost to achieve the same amount of LW gain) are given in Table 7.

Table 7. Cost equivalent of $L W$ losses per farm due to 10 percent rangeland degradation

\begin{tabular}{|c|c|c|}
\hline Number of Lactating Cows per Farm (head) & (a) & 8.5 \\
\hline LW Gain per Cow ${ }^{1}(\mathrm{~kg})$ in Grazing Period & (b) & 12.3 \\
\hline Energy requirement for $1 \mathrm{~kg} \mathrm{LW}$ gain $(\mathrm{MJ})^{2}$ & (c) & 44.0 \\
\hline $\begin{array}{l}\text { Total Energy requirement to re-gain LW loss in case of } \\
10 \% \text { degradation in RC (MJ) }\end{array}$ & $(d=b c)$ & 541.2 \\
\hline Energy Content of Barley DM ${ }^{3}\left(\mathrm{MJ}_{\mathrm{kg}}{ }^{-1}\right)$ & (e ) & 13.0 \\
\hline $\begin{array}{l}\text { Total Barley Requirement per farm Containing } 90 \% \mathrm{DM} \\
(\mathrm{kg})\end{array}$ & $\left(\mathrm{f}=\mathrm{ad}(0.9 \mathrm{e})^{-1}\right)$ & 393.2 \\
\hline Average Barley Price ${ }^{4}\left(€ . \mathrm{kg}^{-1}\right)$ & $(\mathrm{g})$ & 0.8 \\
\hline $\begin{array}{l}\text { Cost Equivalent of LW Loss per Farm Due to } \\
\text { Rangeland Degradation (£) }\end{array}$ & $(\mathrm{h}=\mathrm{fg})$ & 314.6 \\
\hline
\end{tabular}

Source: ${ }^{1}$ from Table $4 ;{ }^{2}$ Anonymous (2012); ${ }^{3}$ Anonymous (2015); ${ }^{4}$ ETB (2018)

The financial equivalent of LW and/or BCS losses in the case of a 10\% setback in $\mathrm{RC}$ due to rangeland degradation was 314.6 Turkish lira (TRY) per farm. Thus, it can be inferred that, ceteris paribus, farmers operating under $10 \%$ better rangeland conditions will likely save 314.6 TRY, or 59.0 USD (I TRY = 0.1875 USD). 
I further estimated that the LW or BCS gain or loss per unit of rangeland area in response to a $10 \%$ enhancement or deterioration of RC was 15.5 TRY or 2.9 USD per hectare of rangeland (Table 8). Thus, ceteris paribus, farms operating with $10 \%$ poorer rangeland condition are likely to pay an extra 15.5 TRY per hectare of rangeland to compensate for the LW or BCS loss compared with their counterparts operating with rangeland in better condition.

Table 8. Estimated total LW or BCS gain or loss per unit rangeland area due to a 10 percent enhancement or setback in $R C$

\begin{tabular}{|c|c|c|}
\hline Total Number of Villages & (a) & 11 \\
\hline Total Rangeland Area (ha) & (b) & 15556 \\
\hline Total Number of Farm Households & (c) & 768 \\
\hline $\begin{array}{l}\text { Energy Feed Cost Equivalent of LW Loss per Farm Due } \\
\text { to Rangeland Degradation }{ }^{1} \text { (TRY) }\end{array}$ & (d) & 314.6 \\
\hline Total Energy Feed Cost Equivalent of LW Loss (TRY) & $(e=c d)$ & 241612.8 \\
\hline $\begin{array}{l}\text { Estimated Cost Equivalent of LW Loss per Unit } \\
\text { Rangeland Area (TRY.ha }{ }^{-1} \text { ) }\end{array}$ & $\left(\mathrm{f}=\mathrm{eb}^{-1}\right)$ & 15.5 \\
\hline
\end{tabular}

Source: ${ }^{1}$ from Table 7

\section{Estimation of the threshold $R C$ value for rangeland restoration}

The total contribution to LW gain made by both rangeland and concentrate supplements at the end of June-October was about $15 \mathrm{~kg}$ (Table 6). The marginal contribution of RC to LW gain was about $10 \mathrm{~kg}(12.3 \pm 1.7 \mathrm{~kg}$ in Table 4 and $13.4 \pm 2.0 \mathrm{~kg}$ in Table 5), and the gap was an extra $10 \mathrm{~kg}$ of $\mathrm{LW}$ gain for full compensation of a 1-point BCS loss $(20 \mathrm{~kg})$ after calving in the absence of supplement use during the grazing season. This is possible in the case of a $10 \%$ enhancement (one-point increment) in RC. Because the average RC was calculated to be 3.3 for the studied rangelands (Table 3), it can be inferred that rangeland with a $4.3 \mathrm{RC}(=3.3+1.0)$ is able to recover BCS losses in full. In another word, rangeland with an RC value below 4.3 is in need of restoration to recover its herbage production potential and fully compensate for the BCS losses of grazing cows.

\section{Discussions}

According to OLS regression results, farmer age had significant $(\mathrm{p}<0.01)$ positive effect on LW gain (Table 4). Contrary to expectations (Rogers, 1983; Lionberger, 1960) but being in tune with Schmit et al. (2007), an explanation for the positive sign and the significance of the variable "farmer age" might be that older farmers are more experienced, and they are more successful in animal keeping. They might have possibly engaged in training activities previously and been able to take timely measures reducing the possibility of unwanted outcomes. On the other hand, although not significant, a positive sign for the schooling variable suggests that the more the schooling years of farmer, the more LW gain per head cow during June-August period. However, it turns to negative for the June-October period probably due to outshining effect of forage scarcity towards the end of the grazing season.

The LW gain differences between the first and second grazing seasons can be explained by higher annual total precipitation in the second year of the study $(357.4 \mathrm{~mm}$ 
in 2006 vs. $436.6 \mathrm{~mm}$ in 2007) and the difference in precipitation between 2006 and 2007 grazing seasons (90.7 $\mathrm{mm}$ in June-August vs. $5.2 \mathrm{~mm}$ in June-October periods) (Table 1). Higher levels of precipitation, especially in June-August period, result in greater herbage production (O'Connor and Rouxt, 1995; Khumalo and Holechek, 2005; Browning et al., 2012), which, in turn, result in higher LW gains.

Of particular note is that the LW gains were lower considering the whole season (June-October period) than that in June-August period in average and especially in draught season. This can be explained by the greater herbage mass during June-August and the decrease in rangeland herbage due to grazing coupled with the decreasing nutrient content of maturing plants over the course of the season (Cook and Harris, 1950, 1979; Cogswell and Kamstra, 1976; Mermer et al., 2011; Koç et al., 2014).

Although, concentrate supplements increased LW gain across all data-collection periods, LW gains driven by concentrates were more distinctive in draught season of the year 2006 than the humid season in the year 2007. Again, cows lost some what they gained during June-August period as the range forage decreases in amount and maturates due to grazing and lignination during the first grazing season of 2006 (Cook and Harris, 1950; Cogswell and Kamstra, 1976; Mermer et al., 2011; Koç et al., 2014).

The present study also revealed that re-scaling effect (Hammami et al., 2009) was of question regarding genetic merit $\mathrm{x}$ environment interaction in both years (i.e. genetic merit $\mathrm{x}$ humidity and genetic merit $\mathrm{x}$ concentrate supplement). That is, performances of the high and low genetic cows differed significantly under different environmental conditions. As seen in Fig. 3, the effect of concentrate supplementation was not the same across the all genotypes. Conforming to Ferris et al. (1999) and Kennedy et al. (2002), local cows responded the least of higher genetic merit cows to concentrate supplementation. In both grazing seasons, 2006 and 2007, purebred cows benefitted the most from the concentrates. However, in humid season responses to concentrate supplementation among the breeds were not as more distinctive as in draught season. This was more likely because of substitution effect since concentrate supplementation can increase total dry matter intake only in case of low herbage allowance (Stockdale, 2000; Delaby et al., 2001; Bargo et al., 2002; Vázquez et al., 2006; Sheahan et al., 2011; Ueda et al., 2016). Due to abundant rangeland forage allowance during humid season and especially in June-August period, concentrate supplementation did not increase total digestible dry matter intake. However, the positive effect of supplements was more obvious in June-October than in June-August, likely because of alleviated substitution effect (Stockdale, 2000) due to decreased forage till the end of the season (Fig. 3).

The OLS regression analysis also revealed that initial LW had a negative and significant effect on LW gain (Tables 3 and 4). This negative effect might be related to the maturity of the cows. Young animals have lower body weight and make higher body weight gains due to development, whereas heavier cows are likely to be mature animals that do not develop as much as young ones. Furthermore, large-frame animals have higher maintenance requirements even after dry-off due to the higher energy requirements of larger vital organs (DiCostanzo et al., 1990), which may cause cows to suffer longer periods of negative net energy balance (Řehák et al., 2012). It should also be remembered that cows usually mature until the age of 5 years (Tüzemen, 1990; Çakır et al., 1995). Therefore, less LW loss and a short period of recovery can be explained by the growth of young animals.

Similar to previous reports, I found that a high stocking rate had a negative and significant $(\mathrm{p}<0.05)$ effect on LW gain (Tables 4 and 5). A low stocking rate may 
result in high output per animal due to selective grazing, or vice versa, because a high stocking rate reduces the degree of selectivity (Hull et al., 1965). Moreover, rangeland herbage production will decrease under heavy or above-carrying-capacity grazing conditions, which result in insufficient dry matter intake and poorer performance of grazing animals (Gökkuş and Koç, 2001).

The results also show that the bare ground rate had a very significant negative effect on LW gain (Table 4) for the period June-August because more bare ground indicates lower levels of herbage production in the rangeland. However, although not significant, the positive relationship between LW gain and the bare ground in the model for June-October period could be explained with the regrowth of grasses with late rainfalls in the season remembering the relatively high correlation $(r=0.4778)$ between the percentage of grasses in botanical composition and high bare ground in the rangeland sites.

On the other hand, the village herds graze under the guidance of herders. In their excursions that start with sunrise and end at sunset (Kara et al., 2014), the total distance they walk every day is several times more than the actual distance between the village and the grazing site decided for the day. The actual distance varies between $360 \mathrm{~m}$ and $6800 \mathrm{~m}$, making an average of $2350 \mathrm{~m}$ in the study area. This implies that the greater is the distance between the village and the target grazing site for the day, the more is the total walking distance for that day. In the present study, the effect of distance on LW gain was shifted from insignificant in June-August period (Table 4) to marginally significant in the June-October period (Table 5). This result suggests that energy cost of walking long distances becomes more apparent as the season proceeds most likely due to decrease in the forage and its lignination because the cost of walking could have only a minor effect on the energy requirement of the grazing cattle (Di Marco et al., 1998) and can be tolerated with abundant rangeland forage allowance. Accordingly, Pratumsuwan (1994) reported that dairy cows with a high productivity can walk horizontally at a comfortable walking speed up to $7.5 \mathrm{~km}$ per day with no significant effect on their milk production if the pasture allowance is not restricted. Similarly, D'Hour et al. (1994) pointed out that walking distances above $6.4 \mathrm{~km}$ only brought about modifications in the yield and composition of the milk.

\section{Conclusion}

The aim of this study was to estimate the threshold RC over which rangelands can compensate BCS and LW losses, and under which restoration is required. This was achieved by revealing the effects of RC on the LW and BCS gains or losses of grazing dairy cows in the presence of farmer, animal- and rangeland-related factors in a socioeconomic environment other than research station trials executed under controlled conditions. This makes the present study important not only for policy makers but also researchers and the others having an interest on rangeland-animal relationships prevailing under on-farm conditions.

Regression analysis showed several significant relations with LW gains in June-August and June-October. Therefore, the dataset and models can be used to draw useful inferences, because the signs of all variables in the models can be explained.

To achieve profitable dairy production by maximising animal potential, it is important to manage BCS, and BCS losses after calving should be compensated for. To this end, RC was shown to be one of the most important factors affecting LW gain or 
loss, and I used this as the proxy for BCS gain or loss during the grazing season. It is critically important to compensate for LW losses and maintain BCS in extensive dairy cattle production. Even a $10 \%$ reduction in RC will likely cause a 0.5 -unit BCS loss in the grazing period when animals are not generally fed with concentrate supplements. The financial equivalent of this LW or BCS loss was calculated to be 314.6 TRY (59.0 USD; 1 TRY=0.1875 USD) per farm and 15.5 TRY (2.9 USD) per hectare of rangeland. However, it should be noted that economic losses may not be limited to energy feed cost equivalents and may include losses related to health disorders, low reproductive performance, and low milk yields. Similar to previous studies, this study showed that concentrate supplements are ineffective during the June-August period, especially in years of good herbage production. Therefore, supplemental feed may not be a good solution to compensate for the BCS or LW losses in June-August.

Nevertheless, this study made it obvious that, after August, grazing cows start to lose LW (Table 5), although they were expected to fully compensate for BCS losses before dry off. I calculated that a LW gain of about $20 \mathrm{~kg}$ was required to increase BCS by one unit. The LW gain at the end of the June-October period was about $15 \mathrm{~kg}$, representing the total contribution of rangeland and concentrate supplement together. However, an additional $5-\mathrm{kg}$ LW gain was required to compensate fully for the 1-unit BCS loss (Table 6). As a short-term solution, grazing cows in the study area and in areas with similar conditions should be given concentrates after August when rangeland herbage is scarce and fully maturated, which in turn, as stated earlier, brings about a more apparent effect of walking long distances on LW gain.

The present study also revealed that Local or indigenous cows exhibited more stable performance in all environmental conditions (Fig. 3). For that reason, I suggest that in extensive dairy production in the study area and the areas sharing similar agroecological and geographic conditions, high genetic merit purebred cows are not a good selection although they have rapid LW gain and so the cows to be used in extensive production should not be higher genetic merit than crossbred genotypes are.

Finally, I estimated that the threshold $\mathrm{RC}$ at which grazing cows fully compensated for BCS losses was 4.3. Therefore, rangeland with an $\mathrm{RC}$ value below 4.3 requires restoration to recover its herbage production potential and fully compensate for the BCS losses of grazing cows. It is evident that rangeland restoration investments are crucial, even considering only BCS losses and disregarding other benefits of rangeland. Yet, follow-up studies are needed to support the findings of this study.

Acknowledgements. This work is part of research project numbered TAGEM/HAYSÜD/05/01/01/01, and entitled "Analysis of the factors affecting milk production and live weight gain in cattle farms dependent on natural grazing lands in Erzurum". The research is financially supported by the former Ministry of Agriculture and Rural Affairs, Turkey. The author extends his gratitude to the Rangeland and Animal Science Teams of Eastern Anatolia Agricultural Research Institute for their valuable work on rangeland vegetation surveys and farm animal live weight records in the study area.

\section{REFERENCES}

[1] Aktaş, M. S., Özkanlar, S., Uçar, O., Özkanlar, Y., Kaynar, Ö., Aytekin, İ. (2011): Relationships between body condition score and some metabolic blood parameters in early lactating dairy cows. - Revue de Médecine Véterinaire 162(12): 586-592. 
[2] Altın, M. (2001): Evolution, Characteristics, Grazing Patterns and Improvement of Grassland Vegetations: Lecture Notes. - Trakya University Faculty of Agriculture, Tekirdağ.

[3] Altın, M., Gökkuş, A., Koç, A. (2005): Meadow and Pasture Rehabilitation. - Ministry of Agriculture and Rural Affairs General Directorate of Agricultural Production and Development Department of Pasture, Meadow and Forage Crops and Basin Development, Ankara.

[4] Anonymous. (2012): DairyNZ Body Condition Scoring: The reference guide for New Zealand dairy farmers. - DairyNZ.

[5] Anonymous. (2013): PROPHET StatGuide: Do your data violate linear regression assumptions? - http://www.basic.northwestern.edu/statguidefiles /linreg_ass_viol.html (Accessed 11 March 2013).

[6] Anonymous. (2015): Feed values. - http://www.dairynz.co.nz/feed /supplements/ feedvalues/ (Accessed 14 February 2015).

[7] Baltagi, B. H. (2005): Econometric Analysis of Panel Data. 3rd ed. - John Wiley and Sons, Chicester, UK.

[8] Bargo, F., Muller, L. D., Delahoy, J. E., Cassidy, T. W. (2002): Milk response to concentrate supplementation of high producing dairy cows grazing at two pasture allowances. - Journal of Dairy Science 85(7): 1777-1792.

[9] Berry, D. P., Macdonald, K. A., Penno, J. W., Roche, J. R. (2006): Association between body condition score and live weight in pasture-based Holstein-Friesian dairy cows. Journal of Dairy Research 73: 487-491.

[10] Berry, D. P., Buckley, F., Dillon, P. (2011): Relationship between live weight and body condition score in Irish Holstein-Friesian dairy cows. - Irish Journal of Agricultural and Food Research 50: 141-147.

[11] Bewley, J. M., Shulz, M. M. (2008): Review: An interdisciplinary review of body condition scoring for dairy cattle. - The Professional Animal Scientist 24: 507-529.

[12] Browning, D. M., Duniway, M. E., Laliberte, A. S., Rango, A. (2012): Hierarchical analysis of vegetation dynamics over 71 years: soil-rainfall interactions in a Chihuahuan desert ecosystem. - Ecological Applications 22(3): 909-926.

[13] Callaghan, K. J., Chen, J. (2008): Revisiting the collinear data problem: an assessment of estimator 'III-conditioning' in linear regression. - Practical Assessment Research \& Evaluation 13: 1-5. http://pareonline.net/getyn.asp (Accessed 30 July 2009).

[14] Cameron, A. C., Trivedi, P. K. (2010): Microeconometrics using Stata. Revised Edition. - Stata Press, College Station, Texas.

[15] Cogswell, C., Kamstra, L. D. (1976): The stage of maturity and its effect upon the chemical composition of four native range species. - Journal of Range Management 29: 460-463.

[16] Cook, C. W., Harris, L. E. (1950): The nutritive value of range forage as affected by vegetation type, site, and state of maturity. - Utah Agricultural Experiment Station Bulletin No.344, http://digitalcommons.usu.edu/uaes_bulletins/305 (Accessed 7 March 2017).

[17] Cook, C. W., Harris., L. E. (1979): Nutritive value of seasonal ranges. - Utah Agricultural Experiment Station Bulletin 472, https://digitalcommons.usu.edu/ uaes_bulletins/350(Accessed 7 March 2017).

[18] Çakır, A., Aksoy, A., Haşimoğlu, S. (1995): Applied Feeding of Farm Animals. - Atatürk University Publications No. 179, Erzurum.

[19] DEFRA (2001): Condition scoring of dairy cows, Department for Environment. - Food and Rural Affairs: 1-12. www.defra.gov.uk/corporate/publications/pubfrm.htm(Accessed 17 September 2015).

[20] Delaby, L., Peyraud, J. L., Delagarde, R. (2001): Effect of the level of concentrate supplementation, herbage allowance and milk yield at turn-out on the performance of dairy cows in mid lactation at grazing. - Animal Science 73: 171-181. 
[21] DeLaval (2006): Efficient cow comfort. - http://www.delaval.com/Global/PDF/ Efficient-cow-comfort.pdf (Accessed 17 September 2015).

[22] De Vries, D. M., De Boer, T. H. A., Diver, J. P. P. (1951): Evaluation of grassland by botanical research in the Netherlands. - In: Proceedings of the United Nationals Scientific Conference on the Conservation and Utilization of Resources 6: 522-524.

[23] D'Hour, P., Hauwuy, A., Coulon, J. B., Garel, J. P. (1994): Walking and dairy cattle performance. - Annales De Zootechnie 43: 369-378.

[24] Di Costanzo, A., Meiske, J. C., Plegge, S. D., Peters, T. M., Goodrich, R. D. (1990): Within-herd variation in energy utilization for maintenance and gain in beef cows. Journal of Animal Science 68: 2156-2165.

[25] Di Marco, O. N., Aello, M. S. (1998): Energy cost of cattle walking on the level and on a gradient. - Journal of Range Management 51(1): 9-13.

[26] Enevoldsen, C., Kristensen, T. (1997): Estimation of body weight from body size measurements and body condition scores in dairy cows. - Journal of Dairy Science 80(9): 1988-1995.

[27] ETB. (2018): Commodity Exchange Bulletin. - Erzurum Commodity Exchange, Erzurum.

[28] Ferris, C. P., Gordon, F. J., Patterson, D. C., Mayne, C. S., Kilpatrick, D. J. (1999): The influence of dairy cow genetic merit on the direct and residual response to level of concentrate supplementation. - Journal of Agricultural Science 132: 467-481.

[29] Gallo, L., Carnier, P., Cassandro, M., Mantovani, R., Bailoni, L., Contiero, B., Bittante, G. (1996): Change in body condition score of Holstein cows as affected by parity and mature equivalent milk yield. - Journal of Dairy Science 79: 1009-1015.

[30] Gintzburger, G., Le Houerou, H. N., Saidi, S. (2006): Near East-West Asia and semiarid rangelands. - Secheresse 17: 152-168.

[31] Gökkuş, A., Koç, A. (2001): Range and Pasture Management. - Atatürk University Faculty of Agriculture Publications No:228, Erzurum.

[32] Gujarati, D. N. (1995): Basic Econometrics. 3rd ed. - McGraw-Hill, New York.

[33] Gujarati, D. N. (2012): Econometrics by example. - Palgrave MacMillan, USA.

[34] Hammami, H., Rekik, B., Gengler, N. (2009): Genotype by environment interaction in dairy cattle. - Biotechnology, Agronomy, Society and Environment 13: 155-164.

[35] Heady, H. F. (1975): Range condition and range trend. - In: Evaluations and Mapping of Tropical African Rangelands. - Proceedings of the Seminar, 3-8 March, International Livestock Centre for Africa Bamako: 177-180.

[36] Holechek, L. J., Pieper, R. D., Herbel, C. H. (2004): Range Ecology. Range Management, Principles and Practices. - Pearson Education, Inc., Upper Saddle River, New Jersey.

[37] Hull, J. L., Meyer, J. H., Sergio, E. B., Weitkamp, W. (1965): Further studies on the influence of stocking rate on animal and forage production from irrigated pasture. Journal of Animal Science 24: 697-704.

[38] Hulsen, J. (2007): Cow Signals: a practical guide for dairy farm management. - Roodbont Publishers, Zutphen.

[39] Jefferies, B. C. (1961): Body condition scoring and its use in management. - Tasmanian Journal of Agriculture 32: 19-21.

[40] Kara, A., Çakal, S., Tavlaş, A., Yazıcı, A., Aygün, C., Avăg A. (2009): Customs and problems in exploiting meadow and pastures in north-east Anatolia. - Alinteri Zirai Bilimler Dergisi 16: 7-18.

[41] Kara, A., Kızıloğlu, S. (2012): Socioeconomic analysis of the livestock farms dependent on natural rangelands in Erzurum. - Turkish Journal of Agricultural Economics 18: 6978 .

[42] Kara, A., Kadıoğlu, S., Dumlu, S. E., Aksakal, E., Özgöz, M. M., Uzun, M., Çakal, Ş., Şimşek, U. (2014): How long does it take to pay back rangeland improvement investments? A case study from Erzurum Province in Turkey. - The Rangeland Journal 36(5): 469-474. 
[43] Kara, A., Şimşek, U., Kadıŏlu, S., Dumlu, S. E., Çakal, Ş., Uzun, M., Aksakal, E., Özgöz, M. M. (2015): Quantifying the financial losses of rangeland degradation due to reduced milk yield in the rangelands of Erzurum Province in Turkey. - The Rangeland Journal 37(5): 459-466.

[44] Kennedy, J., Dillon, P., Rath, M., Faverdin, P., Delaby, L. (2002): The interaction between genotype and concentrate feeding level for milk production with spring-calving Holstein-Friesian dairy cows. - Farm and Food 12(1): 26-28.

[45] Khumalo, G., Holechek, J. (2005): Relationships between Chihuahuan desert perennial grass production and precipitation. - Rangeland Ecology and Management 58(3): 239246.

[46] Koç, A., Gökkuş, A. (1996): Some important features of the plants in rangeland vegetations of Palandöken mountains. - In: Proceedings of the Third National Pasture and Forage Crops Congress of Turkey, 17-19 June: 107-114. Atatürk University Faculty of Agriculture, Erzurum.

[47] Koç, A., Gökkuş, A., Altın, M. (2003): Comparison of the worldwide used methods in the definition of range condition and a suggestion for Turkey. - In: Proceedings of the 5th Field Crops Congress of Turkey, 13-17 October, 2: 36-42, Diyarbakır.

[48] Koç, A., Çakal, Ş. (2004): Comparison of some rangeland canopy coverage methods. In: International Soil Congress Natural Resource Management for Sustainable Development. 7-10 June: 41-45, Erzurum.

[49] Koç, A., Kaya, A., Güllap, M. K., Erkovan, H. İ., Macit, M., Karaoğlu, M. (2014): The effect of supplemental concentrate feed on live weight gain of yearling heifers over grazing season in subirrigated rangelands of East Anatolia. - Turkish Journal of Veterinary and Animal Sciences 38: 278-284.

[50] Lionberger, H. F. (1960): Adoption of New Ideas and Practices. - The Iowa State University Press, Ames.

[51] Ludwig, J. A., Bastin, G. N. (2008): Rangeland condition: its meaning and use. - A Discussion Paper prepared for the Australian Collaborative Rangelands Information System (ACRIS), http://www.environment.gov.au/land/publications/acris /rangelandscondition. html. (Accessed: 6.12.2015).

[52] Mermer, A., Yıldız, H., Ünal, E., Urla, Ö., Aydoğdu, M., Avağ, A., Özgöz, M. M., Aksakal, E., Dumlu, S., Koç, A., Şimşek, U., Özaydın, K. A., Aydoğmuş, O., Dedeoğlu, F., Tuğaç, M. G., Torunlar, H. (2011): Monitoring rangeland vegetation through satellite images (NDVI) in Eastern Anatolia region. - In: Proceedings of the 9. National Field Crops Congress of Turkey, 12-15 September, 3: 1677-1672, Bursa.

[53] Moran, J. (2005): Tropical Dairy Farming: Feeding Management for Small Holder Dairy Farmers in the Humid Tropics. - CSIRO Publications, Melbourne.

[54] Morris, S. T., Kenyon, P. R., Burnham, D. L. (2002): A comparison of two scales of body condition scoring in Hereford $x$ Friesian beef breeding cows. - Proceedings of the New Zealand Grassland Association 64: 121-123.

[55] Neter, J., Wasserman, W., Kutner, M. H. (1989): Applied Linear Regression Models. 2nd ed. - Richard D. Irwin, Boston.

[56] Nielsen, H. M., Friggens, N. C., Lovendahl, P., Jensen, J., Ingvartsen. K. L. (2003): Influence of breed, parity, and stage of lactation on lactational performance and relationship between body fatness and live weight. - Livestock Production Science 79: 119-133.

[57] O'Connor, T. G., Rouxt, P. W. (1995): Vegetation changes (1949-71) in a semi-arid, grassy dwarf shrubland in the Karoo, South Africa: influence of rainfall variability and grazing by sheep. - Journal of Applied Ecology 32: 612-626.

[58] OMAFRA (2015): Body condition scoring of dairy cattle. - Ontario Ministry of Agriculture and Rural Affairs. http://www.omafra.gov.on.ca/english /livestock/ dairy/ facts/00-109.htm (Accessed 8 December 2015). 
[59] Otto, K. L., Ferguson, J. D., Fox, D. G., Sniffen, C. J. (1991): Relationship between body condition score and composition of ninth to eleventh rib tissue in Holstein dairy cows. Journal of Dairy Science 74: 852-859.

[60] Pardini, A. (2009): Rangeland management. - In: Gherardi, F., Corti, C., Gualtieri, M. (eds.) Biodiversity, Conservation and Habitat Management. Encyclopedia of life support systems, Eolss Publishers, 1:236-260, UNESCO, Oxford.

[61] Park, H. M. (2008): Univariate analysis and normality test using SAS, Stata and SPSS, Working Paper. - The University Information Technology Services (UITS), Center for Statistical and Mathematical Computing, Indiana University, Bloomington.

[62] Park, H. M. (2009): Linear regression models for panel data using SAS, Stata, LIMDEP, and SPSS. Working Paper. - The University Information Technology Services (UITS), Center for Statistical and Mathematical Computing, Indiana University, Bloomington.

[63] Pratumsuwan, S. (1994): Effect of Walking Extra Distances on the Performance of Grazing Dairy Cows in Early Lactation. - MSc Thesis -Department of Animal Science, Massey University, Palmerston North, New Zealand.

[64] Řehák, D., Volek, J., Bartoň, L., Vodková, Z., Kubešová, M., Rajmon, R. (2012): Relationships among milk yield, body weight, and reproduction in Holstein and Czech Fleckvieh cows. - Czech Journal of Animal Science 57(6): 274-282.

[65] Roche, J. R., Lee, J. M., Macdonald, K. A., Berry, D. P. (2007): Relationships among body condition score, body weight and milk production variables in pasture-based dairy cows. - Journal of Dairy Science 90(8): 3802-3815.

[66] Rogers, M. E. (1983): Diffusion of innovations. - The Free Press, New York.

[67] Sayar, M. S., Han, Y., Başbağ, M., Gül, İ., Polat, T. (2015): Rangeland improvement and management studies in the Southeastern Anatolia region of Turkey. - Pakistan Journal of Agricultural Sciences 52(1): 9-18.

[68] Schacht, W. H., Reece, P. E. (2009): Impact of livestock grazing on extensively managed grazing lands. - In: McDowell, R. W. (ed.) Environmental Impact of Pasture Based Farming. CAB International.

[69] Schmit, T. M., Chang, H. H., Boisvert, R. N., Tauer, L. W. (2007): Quantifying the contributions to dairy farm business risk: Implications for producer's risk management strategies. - In: EB Series 121879, Cornell University, Department of Applied Economics and Management, New York.

[70] Schröder, U. J., Staufenbiel, R. (2006): Invited review: Methods to determine body fat reserves in the dairy cow with special regard to ultrasonographic measurement of backfat thickness. - Journal of Dairy Science 89: 1-14.

[71] Serin, G. (2004): Effect of body condition score on reproductive performance in dairy cows. - Kafkas Üniversitesi Veteriner Fakültesi Dergisi 10(2): 221-225.

[72] Sheahan, A. J., Kolver, E. S., Roche, J. R. (2011): Genetic strain and diet effects on grazing behavior, pasture intake, and milk production. - Journal of Dairy Science 94: 3583-3591.

[73] Stockdale, C. R. (2000): Levels of pasture substitution when concentrates are fed to grazing dairy cows in northern Victoria. - Australian Journal of Experimental Agriculture 40: 913-921.

[74] Torres-Reyna, O. (2007): Panel data analysis fixed and random effects using Stata (v. 4.2). - Data and Statistical Services, Princeton University, Princeton, www.princeton.edu/ otorres/Panel101.pdf (accessed 2 January 2017).

[75] TURKSTAT (2013): General Agricultural Census, 2001. - Turkish Statistical Institute, Ankara.

[76] TÜMAS (2013): Climatic data. Meteorological Data Archive System of Turkey (TÜMAS). - Turkish State Meteorological Service, Ankara.

[77] Tüzemen, N. (1990): Large Ruminant Husbandry. - Ataturk University Faculty of Agriculture Textbook No: 123, Erzurum. 
[78] Ueda, K., Mitani, T., Kondo, S. (2016): Effect of increased concentrate allotment before evening grazing on herbage intake, nitrogen utilization and rumen fermentation in dairy cows grazed on perennial ryegrass pasture. - Animal Science Journal 87(10): 1233-1243.

[79] Ünal, S., Dedebali, M., Öcal, M. B. (2010): Ecological interpretations of rangeland condition of some villages in Kırıkkale province of Turkey. - Turkish Journal of Field Crops 15(1): 43-49.

[80] Vázquez, O. P., González, A., López, J. (2006): Concentrate supplementation effects on dairy cows grazing Galician pastures during spring. Sustainable grassland productivity. In: Proceedings of the 21 st General Meeting of the European Grassland Federation, Badajoz, Spain, 3-6 April: 194-196.

[81] Williams, R. E., Allred, B. W., Reginald, M. D., Paulsen, H. A. (1968): Conservation, development, and use of the world's rangelands. - Journal of Range Management 21: 355-360.

[82] Yıldız, H., Saat, N., Şimşek, H. (2011): An investigation of body condition score, body weight, calf weight and haematological profile in crossbred dairy cows suffering from dystocia. - Pakistan Veterinary Journal 31(2): 125-128. 